\title{
Biochemical Effects of Sewage Pollution on the Benthic Organism Nerita polita
}

\author{
Munyasya JN1, 2*, Juma KK¹, Burugu MW'1, Mburu DN1 and Okuku EO²
}

${ }^{1}$ Department of Biochemistry and Biotechnology, Kenyatta University, P.O. Box 43844-00100, Nairobi, Kenya

${ }^{2}$ Kenya Marine and Fisheries Research Institute, P.O. Box 81651-80100, Mombasa, Kenya

\begin{abstract}
Degradation of coastal ecosystems is an issue of growing concern. Discharges of sewage effluents to sea water is a major contributor to marine pollution. This study examines the biogeochemical effects of sewage pollution on the condition factor and energy reserves of Nerita polita. A total of 135 molluscs were exposed to varying sewage concentrations of between $5 \%-50 \%$. Physicochemical parameters of the exposure media were characterized using standard techniques. Condition factor of Nerita polita was determined weekly using the Fulton's index. After the exposure period, the molluscs were sacrificed and energy reserves determined. Increase in sewage pollution resulted in elevation of ammonia $(0.01-0.08 \mathrm{mg} / \mathrm{L})$, phosphate $(0.05-156 \mathrm{mg} / \mathrm{L})$, nitrates $(0.02-1.99 \mathrm{mg} / \mathrm{L})$ and temperature $\left(24.34-25.12^{\circ} \mathrm{C}\right)$, while $\mathrm{pH}(7.75$ to 7.29$)$ and dissolved oxygen $(5.62-2.38 \mathrm{mg} / \mathrm{L})$ were lowered. There was no correlation between the condition factor of Nerita polita and the sewage pollution. Glucose, lipid and protein concentrations in the mollusc tissues ranged from $29.6-71.3 \mathrm{mg} / \mathrm{L}, 171-677 \mathrm{mg} / \mathrm{L}$ and $338-445 \mathrm{mg} / \mathrm{L}$, respectively, and they decreased along the increasing sewage gradient. Energy reserves in Nerita polita were highest in lipids, followed by proteins and glucose the least and they were affected by the pollution gradient. Findings of this work suggest that energy reserves are sensitive bio indicators but that conditional factor is an unreliable marker to assess acute sewage toxicity. In addition, increase in sewage pollution also leads to a decrease in the water quality and that sewage concentrations above $30 \%$ can have profound effects on Nerita polita.
\end{abstract}

Keywords: Sewage pollution; Nerita polita; Energy reserves; Condition factor; Bio indicator

\section{Introduction}

Coastal areas are a home to more than half of the world's population and their major economic output is related to activities such as shipping, oil and gas development, tourism and fisheries [1]. Degradation of marine water is an issue of global concern. One of the most serious sources of marine pollution in coastal waters is the discharge of sewage effluents [2]. Sewage pollution is often manifested by elevated concentrations of inorganic nutrients; especially phosphate, nitrates and ammonia [3]. Excess phosphate and nitrates cause eutrophication which increases algal blooms, leading to oxygen depletion and reduction in quality of water, fish, coral, and other marine populations. Society and managers require tools based on sound scientific knowledge to properly monitor, manage and protect the sensitive marine ecosystem. Such tools include chemical analysis of water, use of condition factor and bio indicators [4-6].

Chemical analysis is the most direct approach of sewage toxicity and it involves determination of the physicochemical properties of the exposure media. The most informative physicochemical parameters of water are temperature, $\mathrm{pH}$, oxygen and dissolved inorganic nutrients [7-9], and they formed part of this study. Chemical analysis of the contaminants in marine water has limitations in that it does not provide reliable evidence of the integrated influence and possible toxicity of such pollutants to the organisms and ecosystem $[6,10]$.

Condition factor is one of the indices designed to communicate information about the current status, and when recorded over time, can yield valuable information about changes or trends [11]. Use of condition factor, as an index, provides a way of determining the effect of pollutants or serve as a measure of aquatic pollution by sewage though it is less sensitive than biochemical parameters. Condition factor is affected by a number of additional environmental stressors next to pollutants such as salinity, temperature, infestation with parasites and food under field conditions where such parameters are not easily controlled [12].

Bio monitoring has been applied in a number of places to determine the deleterious effects of sewage pollution. It involves the use of indicators, indicator species or indicator communities to detect changes in water and sediments quality. The presence or absence of a bio indicator is usually interpreted to reflect environmental conditions. The most commonly used bio indicators include benthic macro invertebrates such as molluscs, fish or algae [12].

Molluscs have successfully been used to obtain information on the quality of terrestrial, marine and fresh water ecosystems and to quantify the exposure and effects of contaminants in the environment [13]. They are preferred as good bio indicators because they are abundant, have limited mobility, easy to handle, lack exoskeleton and have limited ability to excrete pollutants. Nerita polita was the test organism of choice because they are highly abundant in tropical marine ecosystems and are filter feeders hence their tissues represent their environment well. Nerita polita, are also non-controversial as organisms for ecotoxicological research, especially as test animals and for environmental monitoring [12].

Due to their sedentary habitat, Nerita polita are exposed to a

${ }^{*}$ Corresponding author: Munyasya JN, Department of Biochemistry and Biotechnology, Kenyatta University, P.O. Box 43844-00100, Nairobi, Kenya, Tel: +254721809 494; Email: joandumi58@gmail.com

Received June 20, 2015; Accepted July 21, 2015; Published July 25, 2015

Citation: Munyasya JN, Juma KK, Burugu MW, Mburu DN, Okuku EO (2015) Biochemical Effects of Sewage Pollution on the Benthic Organism Nerita polita. Environ Anal Toxicol S7: 004. doi:10.4172/2161-0525.S7-006

Copyright: (c) 2015 Munyasya JN et al. This is an open-access article distributed under the terms of the Creative Commons Attribution License, which permits unrestricted use, distribution, and reproduction in any medium, provided the original author and source are credited. 
variety of environmental stressors such as raw sewage and heavy metals especially in urban areas where human population and industrialization has been on the rise [14]. They hence require energy to surpass any physiological stress resulting from sewage toxicity. Energy reserves are the most sensitive stress biomarker in an organism [15]. They are an integrative measure of energy status of an organism at a particular time. Several authors have demonstrated negative effects of pollutants on energy uptake [16-18] and on the energy budget of organisms [19-21]. These findings are limited to Daphnia magna, Dreissena polymorpha, Danio rerio and Mytilus edulis. Similar information on Nerita polita is lacking. This study was therefore conceived with the aim of investigating the biogeochemical effects of sewage pollution on the mollusc Nerita polita by determining its impacts on the condition factor and energy reserves.

\section{Materials and Methods}

\section{Experimental design}

A laboratory bioassay that involved exposure of Nerita polita to serially diluted sewage was conducted to determine impacts of sewage on aquatic ecosystem. A laboratory setting was preferred because large-scale effects on ecosystem results in a challenging research environment as most of the influencing parameters rather than pollution can be controlled or accounted for in the control tank. Since the concentration of sewage differs with the tide cycles with the highest impact occurring during low tides, serial dilutions were made to cover environmentally relevant concentrations. Higher exposure levels above the environmental concentration were included to mimic expected future increase of sewage inputs into the coastal areas.

\section{Sewage}

The molluscs bioassay consisted of nine different concentrations in 19 Litre glass aquariums as follows: Control (tank 1) had 0\% sewage whereas tank 2 , tank 3 , tank 4 , tank 5 , tank 6 , tank 7 , tank 8 and tank 9 had $5 \%, 7.5 \%, 10 \%, 15 \%, 20 \%, 30 \%, 40 \%$ and $50 \%$ of sewage in a total volume of 15 litres, respectively. Tanks 1-4 represented the possible sewage concentrations during high and low tides, whereas tanks 5-9 were included to represent any possible future increase in discharge of sewage. Sewage was obtained from Kenya Marine and Fisheries Research Institute sewage ejector pipe draining in to the Indian Ocean. Fifteen molluscs of length 2-3 centimetres were used in each treatment tank.

\section{Physicochemical analysis}

Water temperature, dissolved oxygen as well as $\mathrm{pH}$ were measured in each treatment tank using a digital YSI probe (Professional plus ${ }^{\circledR}$ Ohio, USA). Ammonia, nitrates and phosphate were determined as described by Parsons et al. [22] and Strickland and Parsons [23]. The physicochemical parameters of the raw sewage were determined along with the sewage treatments at 0900 Hours daily. The raw sewage was expected to have an implication on these parameters because it is a cocktail from wastes from the laboratories, kitchen and washrooms. The wastes vary in composition and concentration and therefore, whether this sewage had an effect on the properties of the receiving waters and living organisms remained to be established by this study.

\section{Condition factor}

The length and weight of mollusc was determined weekly over a three week period. Condition factor was calculated using Fulton's

\begin{tabular}{|c|c|}
\hline Parameter & Mean Values \\
\hline $\mathrm{pH}$ & $7.21 \pm 0.17$ \\
\hline Temperature & $27.37 \pm 0.68^{\circ} \mathrm{C}$ \\
\hline Dissolved oxygen & $1.57 \pm 0.04 \mathrm{mg} / \mathrm{L}$ \\
\hline Ammonia & $2.29 \pm 0.02 \mathrm{mg} / \mathrm{L}$ \\
\hline Nitrates & $8.36 \pm 0.01 \mathrm{mg} / \mathrm{L}$ \\
\hline Phosphates & $280.49 \pm 3.15 \mathrm{mg} / \mathrm{L}$ \\
\hline
\end{tabular}

Table 1: Means of various parameters in raw sewage used for sewage exposure experiment.

mathematical formula [24] as shown below.

$$
\begin{array}{ll}
K=100 \frac{W}{L^{3}} & \\
\text { Where: } & \mathrm{K}=\text { Condition factor } \\
& \mathrm{L}=\text { Length of mollusc in centimetres } \\
& \mathrm{W}=\text { Weight of mollusc in grams }
\end{array}
$$

$100=$ Factor to bring K close to unity.

\section{Energy reserves}

At the end of the experiment, Nerita polita from the same exposure tanks were pooled and homogenised using a home blender. The homogenate was further refined using a homogenizer (Homgen Plus ${ }^{\circledR}$ Gottingen, Germany). The homogenate was kept frozen at $-60^{\circ} \mathrm{C}$ for analysis of energy reserves concentrations (glucose, lipids and proteins). Body glucose content was determined using the Anthrone method [25]. Lipid content was determined by dissolving homogenized tissue in chloroform [26]. Protein was analyzed using the Kjeldahl method as recently described by Magomya et al. [27]. Energy available was calculated by summing the energy values for the different reserves. The enthalpy of combustion for each energy reserve is $24000 \mathrm{~J}$ per one gram of protein, $16000 \mathrm{~J}$ for glucose and $39500 \mathrm{~J}$ for lipids [28].

\section{Statistical analysis}

The condition factor of molluscs as well as the physicochemical properties of exposure media was expressed as mean \pm standard deviation. Pearson product moment correlation was obtained using Minitab 16. This gave $r$ and $p$ values that were used to interpret the relationships between energy reserves, condition factor, physicochemical parameters and dissolved inorganic nutrients and the increasing sewage pollution. In addition, multiple comparisons between the different treatment tanks were determined using ANOVA followed by Tukey's test with Bonferroni adjustment for the physicochemical parameters. The statistical significance was considered at $p<0.05$.

\section{Results}

\section{Characteristics of the raw sewage}

Parameters of the raw sewage are presented in Table 1. The $\mathrm{pH}$ and temperature were within their permissible limits. However, the dissolved oxygen was below the expected minimum value of $4 \mathrm{mg} / \mathrm{L}$ and this posed a direct danger to aquatic organisms in the treatment tanks. The measured value of phosphates was $280.49 \pm 3.15 \mathrm{mg} / \mathrm{L}$ which is 28 times higher than the allowable limit of $10 \mathrm{mg} / \mathrm{L}$. Ammonia and nitrates levels were $2.29 \pm 0.02 \mathrm{mg} / \mathrm{L}$ and $8.36 \pm 0.01 \mathrm{mg} / \mathrm{L}$, respectively, both of which were within permissible limits. 


\begin{tabular}{|c|c|c|}
\hline $\begin{array}{l}\text { Treatment } \\
\text { tank }\end{array}$ & \multicolumn{2}{|l|}{$\begin{array}{l}\text { Sewage } \\
\text { concentration }\end{array}$} \\
\hline 1 & $0 \%$ & $\mathbf{p H}$ \\
\hline 2 & $5 \%$ & $7.75 \pm 0.03$ \\
\hline 3 & $7.5 \%$ & $7.70 \pm 0.01$ \\
\hline 4 & $10 \%$ & $7.70 \pm 0.01$ \\
\hline 5 & $15 \%$ & $7.66 \pm 0.06$ \\
\hline 6 & $20 \%$ & $7.60 \pm 0.08$ \\
\hline 7 & $30 \%$ & $7.57 \pm 0.04$ \\
\hline 8 & $40 \%$ & $7.44 \pm 0.17^{\star}$ \\
\hline 9 & $50 \%$ & $7.29 \pm 0.10^{\star *}$ \\
\hline
\end{tabular}

\begin{tabular}{l}
$\begin{array}{l}\text { Temp } \\
\left({ }^{\circ} \mathrm{C}\right)\end{array}$ \\
\hline $24.34 \pm 0.46$ \\
\hline $24.40 \pm 0.49$ \\
\hline $24.42 \pm 0.48$ \\
\hline $24.50 \pm 0.44$ \\
\hline $24.56 \pm 0.42$ \\
\hline $24.60 \pm 0.39$ \\
\hline $24.70 \pm 0.34$ \\
\hline $24.80 \pm 0.37$ \\
\hline $25.12 \pm 0.46$
\end{tabular}

\begin{tabular}{c}
$\begin{array}{c}\text { Dissolved oxygen } \\
(\mathbf{m g} / \mathrm{L})\end{array}$ \\
\hline $5.62 \pm 0.27$ \\
$5.26 \pm 0.26$ \\
$4.97 \pm 0.24$ \\
$4.81 \pm 0.19$ \\
$4.50 \pm 0.27^{*}$ \\
$4.38 \pm 0.28^{\star}$ \\
\hline $4.10 \pm 0.39^{\star *}$ \\
$3.48 \pm 0.42^{\star *}$ \\
$2.38 \pm 0.26^{\star *}$
\end{tabular}

\begin{tabular}{|l|}
\hline $\begin{array}{l}\text { Ammonia } \\
\text { (mg/L) }\end{array}$ \\
\hline $0.01 \pm 0.01$ \\
\hline $0.01 \pm 0.05$ \\
\hline $0.02 \pm 0.04$ \\
\hline $0.02 \pm 0.05$ \\
\hline $0.03 \pm 0.07$ \\
\hline $0.03 \pm 0.05$ \\
\hline $0.04 \pm 0.05$ \\
\hline $0.06 \pm 0.02$ \\
\hline $0.08 \pm 0.02$ \\
\hline
\end{tabular}

\begin{tabular}{|l}
$\begin{array}{l}\text { Nitrates } \\
\text { (mg/L) }\end{array}$ \\
\hline $0.02 \pm 0.01$ \\
\hline $0.02 \pm 0.01$ \\
\hline $0.02 \pm 0.01$ \\
\hline $0.03 \pm 0.01$ \\
\hline $1.25 \pm 0.91$ \\
\hline $1.47 \pm 0.20$ \\
\hline $1.72 \pm 1.26$ \\
\hline $1.85 \pm 1.38$ \\
\hline $1.99 \pm 1.45$
\end{tabular}

Phosphate (mg/L)

$0.05 \pm 0.01$

$0.26 \pm 0.17$

$0.36 \pm 0.26$

$0.47 \pm 0.30$

$77.82 \pm 3.66^{\star \star}$

$88.69 \pm 2.67^{\text {** }}$

$109.43 \pm 2.91^{\text {** }}$

$144.43 \pm 2.94^{* *}$

$155.92 \pm 2.74^{* *}$

Results are expressed as mean \pm standard deviation of triplicates. The $p$ values are for multiple comparisons between the control and other treatments: ${ }^{*} p<0.05,{ }^{* *} p<0.001$. Table 2: Effects of sewage pollution on the physicochemical properties of marine water.

\section{Effects of sewage on physicochemical properties of marine water}

Table 2 summarises water quality in the nine treatment tanks containing varying levels of sewage pollution. The values in table are the averages of each parameter in each treatment tank over the study period. Tank 1 (control) contained only sea water with no sewage while tank 9 contained the highest amount of sewage (50\%). The water temperature was lowest $\left(24.3^{\circ} \mathrm{C}\right)$ in the control tank and was highest $\left(25.1^{\circ} \mathrm{C}\right)$ in tank 9 . This showed that the temperature of the exposure media increased along the pollution gradient and that there was a significant positive correlation between temperature and sewage concentration $(r=0.978 ; p<0.05)$.

The trend of the $\mathrm{pH}$ was opposite that of the temperature in that there was a gradual drop in $\mathrm{pH}$ with increase in sewage concentration. Exposure media in the control tank had the highest $\mathrm{pH}$ at 7.75 while tank 9 had the lowest $\mathrm{pH}$ of 7.29. Pearson correlation indicated that there was significant negative correlation between $\mathrm{pH}$ and sewage concentration $(r=-0.965 ; p<0.001)$. Dissolved oxygen followed a similar pattern as that of the $\mathrm{pH}$ in that it gradually decreased with the increase in the sewage concentration. The highest levels of dissolved oxygen were observed in tank 1 with $5.6 \mathrm{mg} / \mathrm{L}$ and the lowest levels were in tank 9 with $2.4 \mathrm{mg} / \mathrm{L}$. The amount of oxygen in tank 9 was less than half of that measured in the control tank. Pearson correlation showed a significant negative correlation between dissolved oxygen and the sewage concentration $(r=-0.981 ; p<0.05)$.

Ammonia concentration in the control tank was low $(0.01 \mathrm{mg} / \mathrm{L})$ and as the sewage concentration increased, there was a gradual rise in the ammonia levels. The highest levels of ammonia were recorded in tank $9(0.08 \mathrm{mg} / \mathrm{L})$ which is about 8 times higher than the control. The correlation between ammonia and sewage levels was significantly positive $(r=0.994 ; p<0.001)$. Initially the nitrate levels followed the same pattern as ammonia with the control tank recording a low concentration of $0.02 \mathrm{mg} / \mathrm{L}$ and there was a gradual rise with the increase in the pollution gradient. However, there was a sharp spike in nitrate levels in tank 5 and this increase continued with the highest levels being recorded in tank $9(1.99 \mathrm{mg} / \mathrm{L})$ which had nitrate levels that were over 100 times above those of the control tank. Pearson coefficient indicates a significant positive correlation between nitrates and pollution gradient $(r=0.903 ; p<0.05)$. Phosphate levels followed a similar pattern to that of nitrates in that they increased with increase in pollution gradient, and that there was a sharp spike in tank 5 (77.8 $\mathrm{mg} / \mathrm{L})$. Likewise the highest levels of phosphate were recorded in tank 9 $(156 \mathrm{mg} / \mathrm{L})$ which was over 3,000 times higher than that of the control. Pearson correlation indicated a significant positive relationship between the phosphate and the pollution gradient $(r=0.950 ; p<0.05)$.

Tukey's post hoc analysis of $\mathrm{pH}$ at different sewage concentrations indicated a statistically significant difference at $40 \%(7.44 \pm 0.17$; $p<0.05)$ and $50 \%(7.29 \pm 0.10 ; p<0.001)$ when compared to the control $(7.75 \pm 0.03) . \mathrm{pH}$ levels for all the other treatments were insignificant ( $p$ 0.05) (Table 2). Dissolved oxygen levels were statistically significant at $p<0.05$ for concentrations of $15 \%(4.50 \pm 0.27 \mathrm{mg} / \mathrm{L})$ and $20 \%$ $(4.38 \pm 0.28 \mathrm{mg} / \mathrm{L})$ while concentrations of $30 \%(4.10 \pm 0.39 \mathrm{mg} / \mathrm{L})$, $40 \%(3.48 \pm 0.42 \mathrm{mg} / \mathrm{L})$ and $50 \%(2.38 \pm 0.26 \mathrm{mg} / \mathrm{L})$ were statistically significant at $p<0.001$. Phosphate were significantly $(p<0.001)$ higher at concentrations of $15 \%(77.82 \pm 3.66 \mathrm{mg} / \mathrm{L}), 20 \%(88.69 \pm 2.67$ $\mathrm{mg} / \mathrm{L}), 30 \%(109.43 \pm 2.91 \mathrm{mg} / \mathrm{L}), 40 \%(144.43 \pm 2.94 \mathrm{mg} / \mathrm{L})$ and $50 \%$ $(155.92 \pm 2.74 \mathrm{mg} / \mathrm{L})$ when compared to the control $(0.05 \pm 0.01 \mathrm{mg} / \mathrm{L})$. There was no statistical significant $(p 0.05)$ difference in temperature, ammonia, nitrates for all the nine treatment tanks.

\section{Effects of sewage pollution on the condition factor $(K)$ of Nerita polita}

Table 3 summarises the effect of sewage pollution on condition factor of Nerita polita in the nine treatment tanks. In the control tank, the condition factor was $0.34 \pm 0.37$ in week one, $0.34 \pm 0.08$ in week two and $0.35 \pm 0.09$ in week three. In the tank containing $50 \%$ sewage, the condition factor was $0.33 \pm 0.03$ in week one, $0.38 \pm 0.23$ in week two and $0.29 \pm 0.05$ in week three. Pearson correlation analysis between the $\mathrm{K}$ and increasing sewage pollution showed no distinct trend between the increasing sewage pollution and the condition factor over the study period was not statistically significant. The statistics were $(r$ $=-0.13, p>0.05 ; r=0.34, p>0.05 ; r=-0.22, p>0.05)$ for week 1 , week 2 and week 3 , respectively.

\section{Effect of sewage pollution on glucose levels in the tissues of Nerita polita}

Figure 1 shows the effects of sewage pollution on energy levels in the tissues of the mollusc Nerita polita after the exposure period. The trend of the glucose levels was that there was a gradual drop in the glucose levels in the tissues of molluscs with increase in the pollution gradient. The highest concentration of glucose was recorded in control tank at $71.3 \mathrm{mg} / \mathrm{L}$ while the lowest concentration was found in the molluscs in tank $9(29.6 \mathrm{mg} / \mathrm{L})$, which represents a $58 \%$ drop across the pollution gradient. Pearson coefficient analysis between the glucose levels and increasing sewage pollution indicated a highly significant negative correlation $(r=-0.999$ : $p<0.05)$.

Effect of sewage pollution on lipid levels in the tissues of Nerita polita 


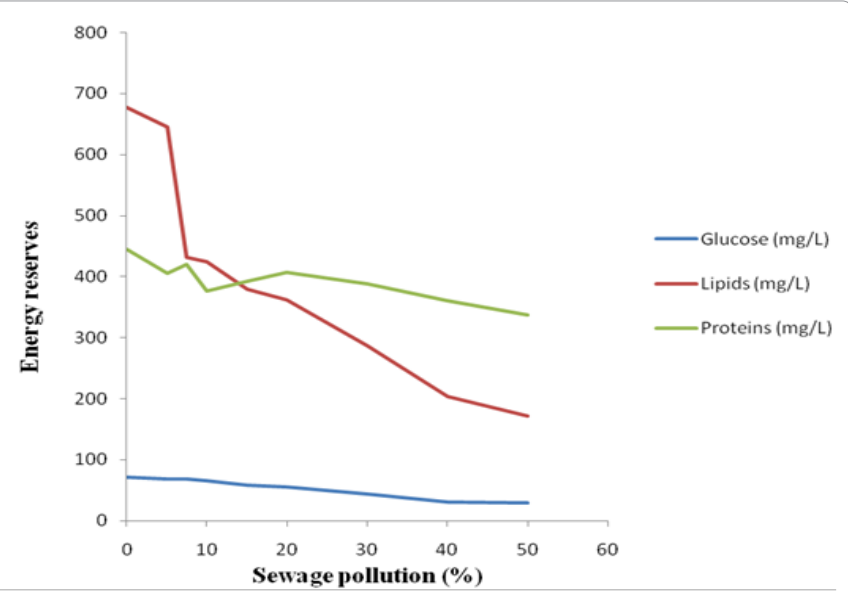

Figure 1: Relationship between energy reserves in the tissues of Nerita polita and the pollution gradient.

The trend of the relationship between lipid levels in tissues of Nerita polita and increasing sewage pollution was similar to that observed with glucose in that increase in sewage pollution was accompanied by decreasing levels of lipids (Figure 1). The highest levels in lipids were recorded in the molluscs harvested in the control tank $(677 \mathrm{mg} / \mathrm{L})$ and the least levels were those in the in the tank containing $50 \%$ sewage $(171 \mathrm{mg} / \mathrm{L})$ which translates to a four-fold difference. There was a sharp drop (33\%) in the lipid levels from $645 \mathrm{mg} / \mathrm{L}$ to $432 \mathrm{mg} / \mathrm{L}$ when sewage concentration was increased from $5 \%$ to $7.5 \%$. Coefficient correlation analysis confirms the existence of a significant inverse relationship between the two variables $(r=-0.914: p<0.05)$.

\section{Effect of sewage on the protein levels in the tissues of Nerita polita}

Just like with glucose and lipids, increase in sewage pollution was also accompanied by a gradual drop in the levels of protein in the tissues of Nerita polita. Figure 1 shows that in the control tank, the protein levels were $445 \mathrm{mg} / \mathrm{L}$ and in the treatment tank with the highest sewage pollution the levels were $338 \mathrm{mg} / \mathrm{L}$, which is a $24 \%$ difference. Pearson correlation indicated a statistically significant relationship between the two variables $(r=-0.97, p<0.05)$.

\section{Effects of sewage on the total energy available in the tissues of Nerita polita}

Table 4 summarizes the total energy available in joules in the tissues of Nerita polita subjected to a sewage pollution gradient. These values were obtained by summing the individual energy values of glucose, lipids, and proteins of all the molluscs in each treatment tank. The major source of energy for Nerita polita was the lipids, followed by proteins while glucose provided the least. For glucose; the amount of energy available to Nerita polita in control tank was $1.1 \mathrm{KJ}$ but only 0.5 $\mathrm{KJ}$ was available in the tank with the highest pollution; for proteins, it was $11 \mathrm{KJ}$ in the control tank versus $8 \mathrm{KJ}$ in the tank with the highest pollution; while for lipids it was $27 \mathrm{KJ}$ in the control tank versus $7 \mathrm{KJ}$ available in the tank with the highest pollution. The drop in energy reserves across the pollution gradient was $27 \%, 55 \%, 74 \%$ for protein, glucose and lipids, respectively. Likewise, the total energy available in the molluscs decreased with the increase in sewage pollution. The control tank recorded the highest levels of total energy of $39 \mathrm{KJ}$ while tank 9 with the highest level of pollution had the least amount of energy $(15 \mathrm{KJ})$, which represents a $62 \%$ drop across the pollution gradient. The difference in energy levels in the two tanks is by a factor of 4.23. Pearson correlation indicates a statistically significant negative correlation between energy levels and increasing pollution $(r=-0.93$ : $p<0.05)$.

\section{Discussion}

\section{Effects of sewage on physicochemical properties of marine water}

The temperature of the treatment media was found to increase with the increase in sewage concentration, while for $\mathrm{pH}$ the trend was opposite. Elevation of water temperature was attributed to the warming effect from the heat generated during the decomposition of the organic matter. Accompanying decomposition is the release of carbonic acid that lowers the $\mathrm{pH}$ of the exposure media; here it was reduced from 7.75 in unpolluted water to 7.29 in the marine water containing $50 \%$ sewage. Water temperature is critical for marine life and it has been shown to affect the solubility of dissolved gases, rate of growth of aquatic plants, algae, and other marine organisms.

There was a significant decrease in dissolved oxygen across the increasing pollution gradient, in the tanks containing $40 \%$ and $50 \%$ sewage, the oxygen levels were reduced to $3.5 \mathrm{mg} / \mathrm{L}$ and $2.4 \mathrm{mg} / \mathrm{L}$, respectively. Reduction in the amount of dissolved oxygen is attributed to high temperature and increased microbial activity following decomposition of organic matter [9,29]. The internationally acceptable minimal permissible levels of dissolved oxygen for aquatic life are 4 $\mathrm{mg} / \mathrm{L}$ [4]. Levels below $4 \mathrm{mg} / \mathrm{L}$ put stress on aquatic life and levels of less than $2 \mathrm{mg} / \mathrm{L}$ may result in death of molluscs [30]. Therefore, sewage concentrations of $40 \%$ and above are likely to be stressful to the mollusc Nerita polita.

Ammonia levels ranged from $0.01 \mathrm{mg} / \mathrm{L}$ in the control tank to 0.08 $\mathrm{mg} / \mathrm{L}$ in the tank with the highest pollution. Due to lack of toxicity data with marine organisms the minimum permissible limit for ammonia in salty water is still controversial. Nevertheless, based on acute and chronic toxicity data the tentative limits for ammonia have been set at $0.035 \mathrm{mg} / \mathrm{L}$ [31]. Boardman et al. [32] suggested that these levels should be significantly increased from $0.035 \mathrm{mg} / \mathrm{L}$ to $0.081 \mathrm{mg} / \mathrm{L}$. Thus, according to United States Environmental Protection Agency criterion it can be concluded that Nerita polita is safe up to a sewage concentration of $20 \%$, but according to the Boardman criterion the ammonia concentrations in all the treatment media were within the allowable limits. This result therefore indirectly support the adjusted high limit values of ammonia as there was no recorded adverse effects or impairment on the growth of Nerita polita even in the treatment tank with an ammonia concentration of $0.08 \mathrm{mg} / \mathrm{L}$.

Ammonia is oxidized to nitrates and as s a result, the concentration of nitrates in fresh water and marine systems is higher than that of ammonia [33], an observation that is consistent with the findings of this study, where the levels of nitrates ranged from $0.02 \mathrm{mg} / \mathrm{L}$ to $1.99 \mathrm{mg} / \mathrm{L}$ while those of ammonia were lower and ranged from $0.01 \mathrm{mg} / \mathrm{L}$ to 0.08 $\mathrm{mg} / \mathrm{L}$. The internationally accepted maximum high limit for nitrates in portable water is $10 \mathrm{mg} / \mathrm{L}$ [4]. The Canadian Council of Ministers of the Environment [34] recommended water quality criteria ranging of $2.9-3.6 \mathrm{mg} / \mathrm{L}$ to protect fresh water and marine life, while Camargo et al. [35] proposed a maximum level of $2 \mathrm{mg} / \mathrm{L}$ for the protection of sensitive aquatic animals. Here the highest levels of nitrate was 1.99 $\mathrm{mg} / \mathrm{L}$ and thus within permissible limits.

Sewage concentration of $15 \%$ and above recorded very high levels of phosphate, above $77 \mathrm{mg} / \mathrm{L}$, and these have the potential of causing 


\begin{tabular}{|c|c|c|c|c|}
\hline Treatment tank & Sewage concentration & Week 1 & Week 2 & Week 3 \\
\hline 1 & $0 \%$ & $0.34 \pm 0.37$ & $0.34 \pm 0.08$ & $0.35 \pm 0.09$ \\
\hline 2 & $5 \%$ & $0.34 \pm 0.05$ & $0.33 \pm 0.03$ & $0.32 \pm 0.06$ \\
\hline 3 & $7.5 \%$ & $0.35 \pm 0.13$ & $0.35 \pm 0.11$ & $0.33 \pm 0.02$ \\
\hline 4 & $10 \%$ & $0.33 \pm 0.21$ & $0.38 \pm 0.23$ & $0.37 \pm 0.14$ \\
\hline 5 & $15 \%$ & $0.35 \pm 0.13$ & $0.34 \pm 0.11$ & $0.33 \pm 0.09$ \\
\hline 6 & $20 \%$ & $0.34 \pm 0.12$ & $0.34 \pm 0.12$ & $0.36 \pm 0.13$ \\
\hline 7 & $30 \%$ & $0.36 \pm 0.05$ & $0.34 \pm 0.09$ & $0.33 \pm 0.11$ \\
\hline 8 & $40 \%$ & $0.34 \pm 0.09$ & $0.34 \pm 0.12$ & $0.38 \pm 0.21$ \\
\hline 9 & $50 \%$ & $0.33 \pm 0.03$ & $0.38 \pm 0.23$ & $0.29 \pm 0.05$ \\
\hline
\end{tabular}

Results are expressed as mean \pm standard deviation for $\mathrm{N}=15$.

Table 3: Effects of sewage pollution on the condition factor $(\mathrm{K})$ of Nerita polita.

\begin{tabular}{|c|c|c|c|c|c|}
\hline Treatment tank & $\begin{array}{c}\text { Sewage } \\
\text { concentration }\end{array}$ & $\begin{array}{l}\text { Glucose } \\
\text { (Joules) }\end{array}$ & $\begin{array}{c}\text { Lipid } \\
\text { (Joules) }\end{array}$ & $\begin{array}{c}\text { Protein } \\
\text { (Joules) }\end{array}$ & $\begin{array}{c}\text { Total energy } \\
\text { (Joules) }\end{array}$ \\
\hline 1 & $0 \%$ & 1141 & 26753 & 10690 & 38585 \\
\hline 2 & $5 \%$ & 1105 & 25474 & 10085 & 36664 \\
\hline 3 & $7.5 \%$ & 1097 & 17069 & 9782 & 27949 \\
\hline 4 & $10 \%$ & 1049 & 16751 & 9748 & 27550 \\
\hline 5 & $15 \%$ & 933 & 14989 & 9429 & 25352 \\
\hline 6 & $20 \%$ & 890 & 14296 & 9311 & 24498 \\
\hline 7 & $30 \%$ & 711 & 11321 & 9059 & 21093 \\
\hline 8 & $40 \%$ & 507 & 8029 & 8673 & 17209 \\
\hline 9 & $50 \%$ & 474 & 6780 & 8101 & 15356 \\
\hline
\end{tabular}

Results are expressed as a summation for $\mathrm{N}=15$.

Table 4: Changes in the energy levels in the whole body tissues of Nerita polita exposed to various sewage concentrations after the experimental period.

algae bloom leading to eutrophication and depletion of dissolved oxygen in water. Excess phosphates are mainly contributed by sewage pollution and agricultural runoff, and they can cause eutrophication [36], which in turn poses problems of hypoxia and anoxia to marine life and thus affecting aquatic resources. Several studies have reported mass mortalities of marine organisms arising from hypoxia [8,37]. A review of the literature indicates that there is insufficient information available on acute aquatic toxicity assessment of phosphate. Based on a recent study by Kim et al. [38], phosphates with a nominal concentration above $100 \mathrm{mg} / \mathrm{L}$ possessed no direct toxicity to aquatic organisms. So it requires very high levels of phosphorous to express toxicity in marine organisms.

\section{Effects of sewage pollution on the condition factor (K) of Nerita polita}

Condition factor of Nerita polita was determined using the Fulton's condition index. This study revealed that Fulton's index was inconsistent despite a consistent increasing pollution gradient. Zafar and Ayub [39] also reported non-significant differences in the condition factor of the limpet Cellana karachiensis sampled in different seasons at two sites. Condition factor is determined using the weight and length of the mollusc. Out of the two parameters, weight is expected to vary more than the length because weight of the Nerita polita can be directly interfered by other factors such as reduction of food readily available for the mollusc in its environment among others. Toxins in sewage affect the growth of Nerita polita by changing their metabolism and thus requiring the mollusc to increase energy for maintaining homeostasis rather than growth and reproduction. This implies that condition factor is not an informative tool for studying acute toxicity in Nerita polita.

\section{Effect of sewage pollution on glucose, lipid, protein and energy reserves}

Carbohydrate, lipid and protein contents of the whole body tissues showed a decrease with the increase in the sewage concentration. These findings are consistent with the observations made on two species of molluscs (Unio tigridis and Viviparus bengalensis) collected in Euphrates River [40]. Decrease in glucose reserves was probably due to glycogenolysis and utilization of glucose to meet increased metabolic cost. In response to carbohydrate depletion, molluscs use other substrates to obtain the energy needed for its maintenance through gluconeogenesis such as lipids. The lipid reserves were also seen to decrease as the sewage concentration in the treatment media increased. This observation was in agreement with a previous study by Capuzzo et al. [41] which observed reduction in triacylglycerol synthesis and decreased mobilization of essential fatty acids to phospholipid pools at the biochemical level due to contaminants. It is also possible that the decrease in lipids and proteins can be attributed partly due to their utilization in cell repair due to corrosion of plasma membranes by some toxicants in sewage [42].

Just like the previous two biomolecules, there was evidence of decline of protein concentration in the tissues as the sewage concentration increased. The regulation of global protein synthesis represents an important adaptive strategy for a response to cellular stress [43]. Reduction of protein contents of Nerita polita under sewage toxicity stress could be attributed to use of various aminoacids in various catabolic reactions as well as muscle wasting indicating a 
starvation response. Fall in protein content may also be due to altered enzyme activities [44].

Bio monitoring is a technique used to assess the environment based on analysis of an individual organism's contents. The markers used are principally toxins and biological changes. The latter is in form of energy reserves as reported by Nahrgang et al. [45]. Demands for the energy reserve in marine organisms are not constant, and they are affected by exogenous factors such as food availability, temperature, $\mathrm{pH}$, dissolved oxygen and sewage pollution. Indicator species used in bio monitoring are mainly the benthic macro invertebrates such as the mollusc. Analysis of whole body tissues of Nerita polita showed that energy reserves were highest in lipids, followed by protein and carbohydrates and that these reserves were affected by the pollution gradient. These findings are in agreement with the observations made in the molluscs Daphnia magna, Dreissena polymorpha, Danio rerio and Mytilus edulis [16-21]. In conclusion the findings of this work suggest that energy reserves are sensitive bio indicators but that conditional factor is an unreliable marker to assess acute sewage toxicity. In addition, increase in sewage pollution also leads to a decrease in the water quality and that sewage concentrations above $30 \%$ can have profound effects on Nerita polita.

\section{Acknowledgement}

We wish to thank the Director of Kenya Marine and Fisheries Research Institute for providing us with an opportunity of studentship. Sincere gratitude goes to KMFRI technologists in the Environmental Pollution, Natural Products and Wet laboratories for extending to me their invaluable advice and experience which they willingly shared during the experimental period and laboratory analysis.

\section{Conflict of Interest}

The authors have no conflicts of interest.

\section{References}

1. Cicin-Sain B, Belfiore $S$ (2005) Linking marine protected areas to integral coastal and ocean management: A review of theory and practice. Ocean Coastal Manag 48: 847-868.

2. Schlacher TA, Liddell B, Gaston TF, Schlacher-Hoenlinger M (2005) Fish track wastewater pollution to estuaries. Oecologia 144: 570-584.

3. Fabricius KE (2005) Effects of terrestrial runoff on the ecology of corals and coral reefs: review and synthesis. Mar Pollut Bull 50: 125-146.

4. Shanmugam P, Neelamani S, Ahn YH, Philip L, Hong GH (2007) Assessment of the levels of coastal marine pollution of Chennai City, Southern India. Water Res Manag 21: 1187-1206.

5. Udo PJ (2013) Length -Weight / Girth Relationship and Condition Factor of the Periwinkle Tympanotonus fuscatus, (Cerithidae: Gastropoda) of the Cross River, Nigeria. Int J Fish Aquat St 1: 26-28.

6. Zhou Q, Zhang J, Fu J, Shi J, Jiang G (2008) Biomonitoring: an appealing tool for assessment of metal pollution in the aquatic ecosystem. Anal Chim Acta 606: 135-150.

7. Espinosa F, Guerra-Garci JM, Garcia-Gomez JC (2007) Sewage pollution and extinction risk: An endangered limpet as a bio indicator? Biodivers Conserv 16: 377-397.

8. Jack JP, Abdsalam AT, Khalifa NM (2009) Assessment of dissolved oxygen in coastal waters of Benghazi, Libya. J Black Sea Mediterr Environ 15: 135-156.

9. Patil PN, Sawant DV, Deshmukh RN (2012) Physicochemical parameters for testing of water - A review. Int J Environ Sci 3: 1194-1207.

10. Adjei B, Obionkorang D, Amisah S (2010) Bioaccumulation of heavy metals in tissue of the clam Galatea paradoxa and sediments from Volta estuary Ghana. Int J Environ Reserve 4: 533-540.

11. National Research Council (2000) Ecological indicators for the nation. National Academy Press. Pp180.
12. Oehlmann J, Schulte-Oehlmann U (2003) Molluscs as bio-indicators In: Market BA, Breure AM, Zechmeister G (eds) Bioindicators \& Biomonitors Principles, Concepts and Applications. Elsevier Science Publishers, New York, NY pp: 577-635.

13. Markert B, Wappelhorst O, Weckert V, HerpinU, Siewers U, et al. (1999) The use of bio indicators for monitoring the heavy-metal status of the environment J Radioanal Nucl Chem 240: 425-429.

14. Boening DW (1999) An evaluation of bivalves as bio monitors of heavy metals pollution in marine waters. Environ Monit Assess 55: 459-470.

15. Widdows J, Donkin P, Brinsley M, Evans S, Salkeld P, et al. (1995) Scope for growth and contaminant levels in North Sea mussels Mytilus edulis. Mar Eco Prog Ser 127: 131-148.

16. Kraak MHS, Kuipers F, Schoon H, Degroot CJ, Admiraal W (1994a) The filtration-rate of the zebra mussel Dreissena polymorpha used for water-quality assessment in Dutch rivers. Hydrobiologia 294: 13-16.

17. Kraak MHS, Lavy D, Schoon H, Toussaint M, Peeters WHM, et al. (1994b) Ecotoxicity of mixtures of metals to the zebra mussel Dreissena polymorpha. Environ Toxicol Chem 13: 109-114.

18. Knops M, Altenburger R, Segner H (2001) Alterations of physiological energetics, growth and reproduction of Daphnia magna under toxicant stress. Aquat Toxicol 53: 79-90

19. Smolders R, Bervoets L, Blust R (2002) Transplanted zebra mussels (Dreissena polymorpha) as active biomonitors in an effluent-dominated river. Environ Toxicol Chem 21: 1889-1896.

20. Widdows J, Donkin P, Staff FJ, Matthiessen P, Law RJ, et al. (2002) Measurement of stress effects (scope for growth) and contaminant levels in mussels (Mytilus edulis) collected from the Irish Sea. Mar Environ Res 53: 327 356.

21. De Coen WM, Janssen CR (2003) The missing biomarker link: relationships between effects on the cellular energy allocation biomarker of toxicant-stressed Daphnia magna and corresponding population characteristics. Environ Toxicol Chem 22: 1632-1641.

22. Parsons TR, Maita Y, Lalli CM (1984) A manual of chemical and biological methods for seawater analysis. Pergamon Press. Pp 173.

23. Strickland JDH, Parsons TR (1968) A practical handbook of sea water analysis. Bulletin Fisheries Research Agency Canada p: 22-28.

24. Ricker WE (1971) Methods of assessment of fish production in fresh waters Blackwell Scientific Publishers, Oxford, London p: 313.

25. Hedge JE, Hofreiter BT (1962) Carbohydrate Chemistry In: Whistler RL, Be Miller JN, Academic Press, New York P: 420.

26. Bligh EG, Dyer WJ (1959) A rapid method of total lipid extraction and purification. Can J Biochem Physiol 37: 911-917.

27. Magomya AM, Kubmarawa D, Ndahi JA, Yebpell GG (2014) Determination of Plant Proteins via the Kjeldahl Method and Amino Acid Analysis: A Comparative Study. Inter J Sci Tech Res 3: 68-72.

28. Chebbaki K, Talbaoui EA, Abrehouch A, Ali AA, Sedki S, et al. (2010) Effect of fish meal replacement by protein sources on the extruded and pressed diet of European sea bass juvenile (Dicentrarchus labrax). Agric Bio J N Amer 1 : 704-710.

29. United States Environmental Protection Agency (2006) Voluntary Estuary Monitoring Manual Chapter 9: Dissolved Oxygen and Biochemical Oxygen Demand p: 2.

30. Moore JW (1991) Inorganic contaminants of surface water: Research and monitoring priorities. Springer-Verlag, New York.

31. United States Environmental Protection Agency (1989) Ambient Water Quality Criteria for Ammonia (Saltwater)-1989.EPA 440/5-88-004 Office of Wate Regulations and Standards, Criteria and Standards, Washington D.C. USA.

32. Boardman GD, Starbuck SM, Hudgins DB, Li X, Kuhn DD (2004) Toxicity of ammonia to three marine fish and three marine invertebrates. Environ Toxico 19: $134-142$.

33. Rabalais NN, Turner RE, Dortch Q, Justic D, Bierman VJ, et al. (2002) Nutrientenhanced productivity in the northern Gulf of Mexico: Past, Present and Future. Hydrobiologia 475: 39-63. 
Citation: Munyasya JN, Juma KK, Burugu MW, Mburu DN, Okuku EO (2015) Biochemical Effects of Sewage Pollution on the Benthic Organism Nerita polita. J Environ Anal Toxicol S7: 004. doi:10.4172/2161-0525.S7-006

34. Canadian Council of Ministers of the Environment (2003) Canadian water quality guidelines for the protection of aquatic life: nitrate ion. Winnipeg, Canada P: 1-17.

35. Camargo JA, Alonso A, Salamanca A (2005) Nitrate toxicity to aquatic animals: a review with new data for freshwater invertebrates. Chemosphere 58: 12551267.

36. Sharp JH (1991) Review of carbon, nitrogen, and phosphorus biogeochemistry Rev Geophy 29: 648-657

37. Diaz RJ, Rosenberg R (1995) Marine benthic hypoxia: A review of its ecological effects and the behavioral responses of benthic macrofauna. Oceanogr Mar Biol Ann Rev 33: 245-303.

38. Kim E, Yoo S, Ro HY, Han HJ, Baek YW, et al. (2013) Aquatic toxicity assessment of phosphate compounds. Environ Health Toxicol 28: e2013002.

39. Zafar FHS, Ayub Z (2013) Allometric variations and condition factor in Cellana karachiensis (Winckworth, 1930) found at two adjacent rocky coasts of Karachi, Pakistan. Ind J Geo-Mar Sci 42: 794-799.

This article was originally published in a special issue, Toxicology \& Environmental Safety handled by Editor(s). Dr. Abdel-Tawab H. Mossa, National Research Centre, Egypt

Citation: Ranjeeta (2015) Removal of Fluoride from Drinking Water Using Fly Ash after Pre Treatment. J Environ Anal Toxicol S7: 004. doi:10.4172/2161 0525.S7-006
40. Salman JM, Nasar AJ (2013) Total lipids and total protein in two mollusc species as environmental biomarkers of pollution in Euphrates River, Iraq. Int $J$ Curr Microb App Sci 2: 207-214.

41. Capuzzo JM, Lancaster BA, Sasaki GC (1984) The effects of petroleum hydrocarbons on lipid metabolism and energetics of larval development and metamorphosis in the american lobster Homarus armericanus (Milne Edwards). Mar Environ Res14: 201-228.

42. Harper AH (1983) Review of Biochemistry. Lange Medical Publications Company, California P: 1012.

43. Ivanina AV, Taylor C, Sokolova IM (2009) Effects of elevated temperature and cadmium exposure on stress protein response in eastern oysters Crassostrea virginica (Gmelin). Aquat Toxicol 91: 245-254.

44. Jadhav ML, Lomte VS (1982) Biochemical composition of the freshwater bivalve Lamellidens marginalis. Riv Di Idrobiol 21: 1-3.

45. Nahrgang J, Brooks SJ, Evenset A, Camus L, Jonsson M, et al. (2013) Seasonal variation in biomarkers in blue mussel (Mytilus edulis), Icelandic scallop (Chlamys islandica) and Atlantic cod (Gadus morhua): implications for environmental monitoring in the Barents Sea. Aquat Toxicol 127: 21-35.
Submit your next manuscript and get advantages of OMICS Group submissions

Unique features:

- User friendly/feasible website-translation of your paper to 50 world's leading languages

Audio Version of published paper

Digital articles to share and explore

Special features:

- 400 Open Access Journal

30,000 editorial team

21 days rapid review process

- Quality and quick editorial, review and publication processing

- Indexing at PubMed (partial), Scopus, EBSCO, Index Copernicus and Google Scholar etc

- Sharing Option: Social Networking Enabled

- Authors, Reviewers and Editors rewarded with online Scientific Credits

- Better discount for your subsequ

Submit your manuscript at: www.omicsonline.org/submission/ 